GB

701

.W375

no.78-11

1978

\title{
EFFECTS OF URBAN DEVELOPMENT \\ ON THE FLOOD-FLOW CHARACTERISTICS \\ OF THE WALNUT CREEK BASIN \\ DES MOINES METROPOLITAN AREA, IOWA
}

U. S. Geological Survey

Water-Resources Investigations 78-11

Preparod in cooperation with tho

lowa Natural Resources Council

STATE LIBRARY OF IOWA

Historical Building

DES MOINES, IOWA 50319

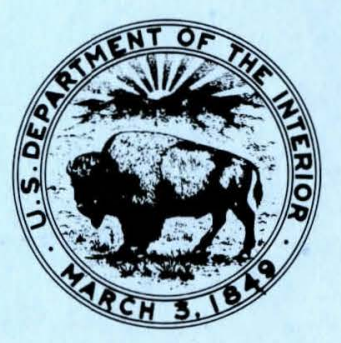




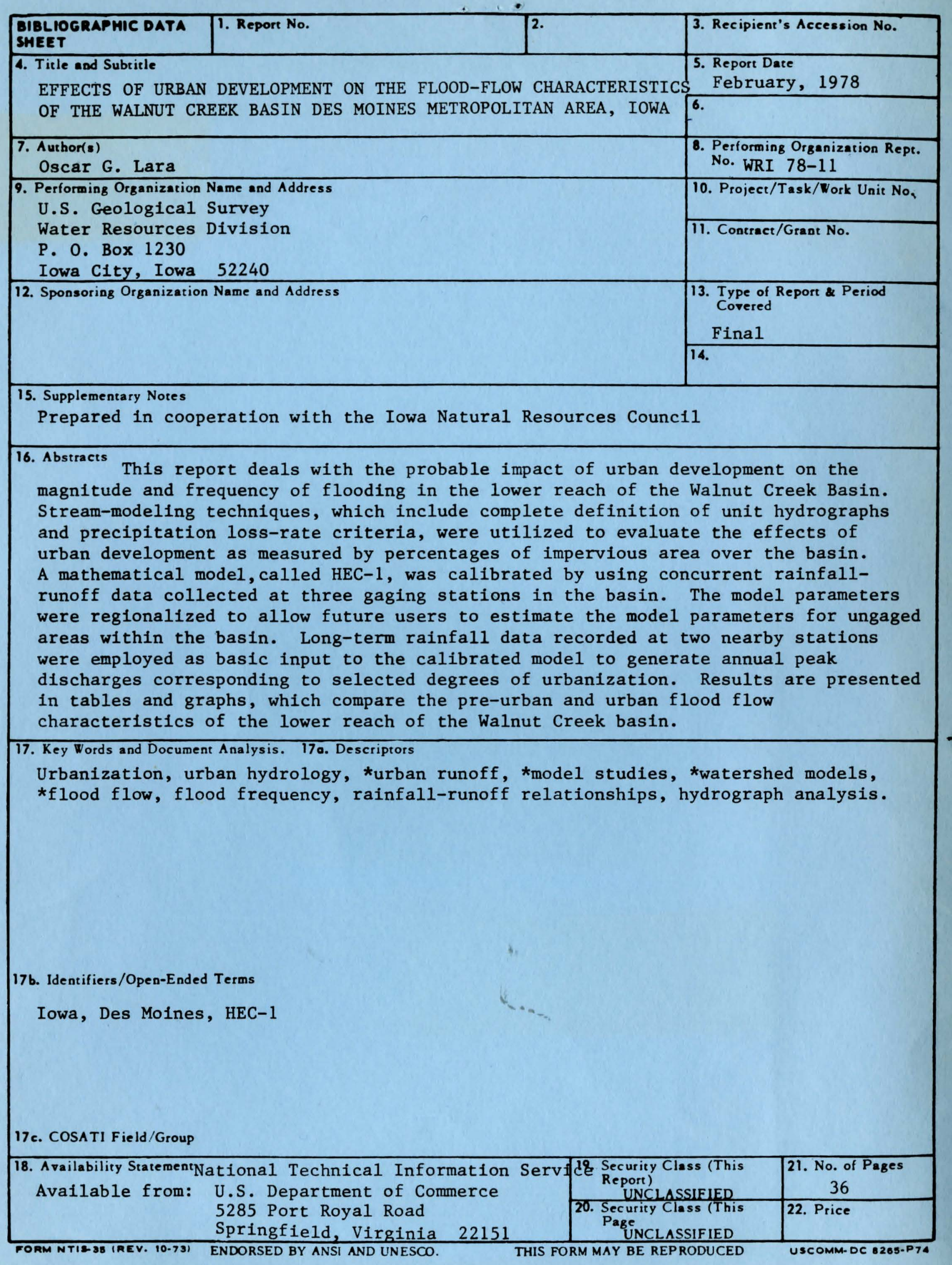

EFFECTS OF ORBAN DEVELOPMENT

ON THE PLOOD-F LON CHARACTERISTICS

OF THE WALNUT CREEK BASIN

DES MOINES METROPOLITAN AREA, IOHA

Oscar G. Lara

Hyd rologist
o.s. Geological Survey

Prepared by the

o.S. Geological Survey

in cooperation with

THE IOHA NATURAL RESOURCES COUNCII

February 1978
GTAFE LIBRARY OF IOWA Histerical Building

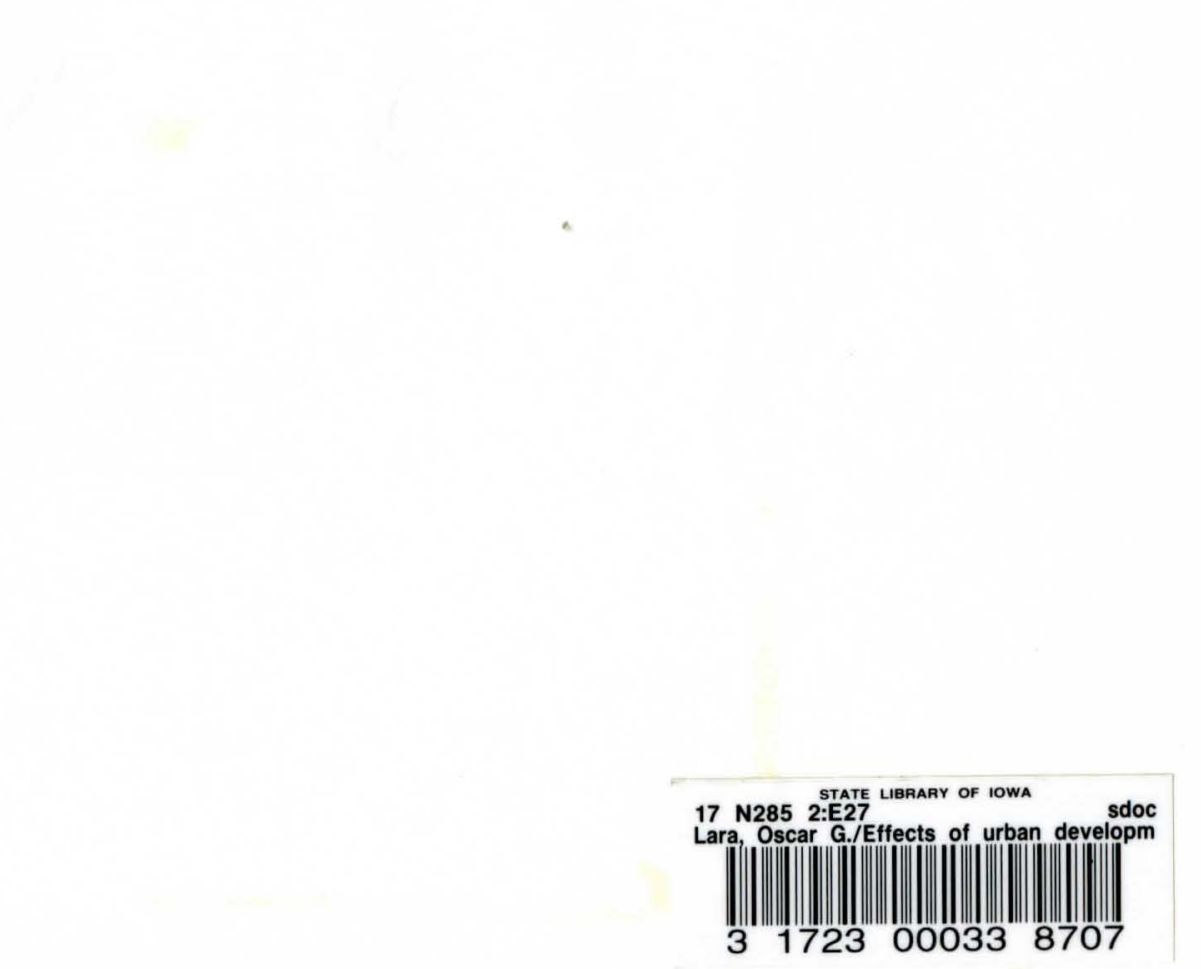


ONITED STATES DEPARTHENT OF THE INTERIOR

Cecil D. Andrus, Secretary

GEOLOGICAL SURVEY

$$
\begin{aligned}
& \text { W. A. Radlinski } \\
& \text { Acting Director }
\end{aligned}
$$

STATE OF IOHA

Robert D. Ray, Governor

ION A NATURAL RESOURCES COUNCII

Merwin D. Dougal, Chairman, Ames erry L. Christensen, Vice-chairman, Diagonal Joyce Conklin - Repp, Secretary, Minburn

leigh R. Curran, Mason City

arvin A. Dalchow, Maquoketa

Hugh Templeton, Knoxille

John P. Whiteseli, Iowa Falls

Sandra A. Ya tes, Ottuma

Louis F. Gieske, Pater Commissioner

\section{CONTENTS}

Abstract.

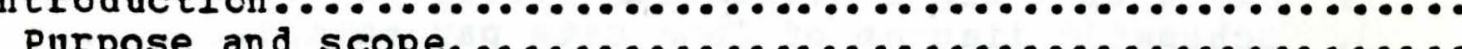

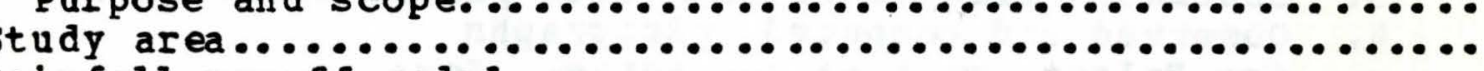

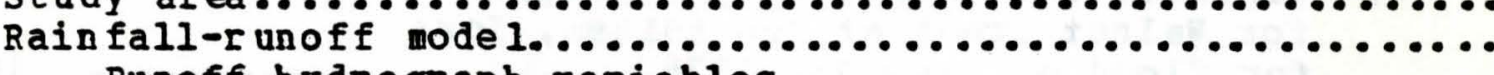

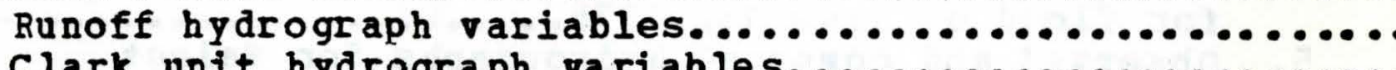

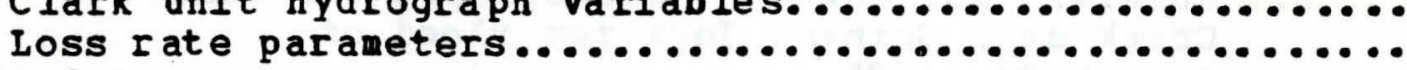

Basic data.........................................

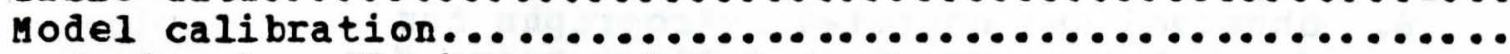

Regional analysis of nodel parameters................

Modeling sequence...............................

Results of regional analysis..................... 17

Runoff hydrograph variables...................... 17

Clark unit hydrograph variables................... 17

Loss $r$ ate parameters..$\ldots \ldots \ldots \ldots \ldots \ldots \ldots \ldots \ldots \ldots \ldots \ldots$

Synthesis of flood peaks.......................... 18

Processing of rainfall data....................... 18

Simulation of peaks............................. 21

Results. .................................. 22

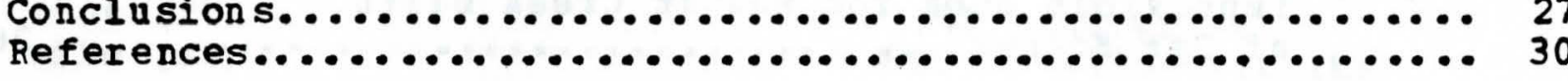


Figure 1. Map of ralnut Creek basin.................. 5

Schematic diagram of loss rate

and computed hy drographs

for Walnut Creek at Des Moines, Iowa

for flood of June 18, 1975.......................14

observed and computed hydrographs for Walnut

creek near Grimes, Iowa for flood of

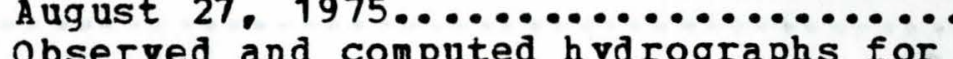

North Walnut Creek at College Drive for

f Relation between TC+R and the drainage

FACTORS FOR CONVERTING ENGLISH ONITS TO

8. area for Wa lnut Creek basin...................

of urbanization as measured by increased

percentage of impervious area for

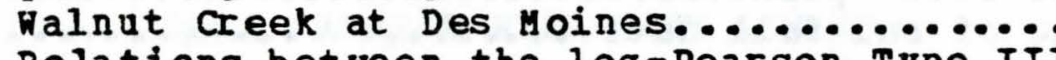

- Relations between the log-pearson Type III

distribtuion parameters and percentage

inpervions area for Halnut creek basin

TABLES

Table 1. Synthetic annual peak discharges in

cubic feet per second compiled from

model responses to present conditions

and to selected degrees of urbanization............

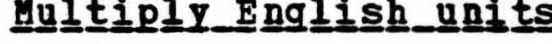

inch (in)

foot (ft)

square feet (sq $f t$ )

(sg $m i)$

cubic feet per second (cfs)
By To_obtain__sI_ungits

LENGTH

25.40 millimeter (mm)

.3048 meter (m)

1.609 kilometer (km)

AREA

.093 square meters (m2)

square $k i$ loneters $\left(\mathrm{km}^{2}\right)$

FLOR

.02832 cubic meters per

second $\left(m^{3} / s\right)$ 
ON THE FLOOD-FLON CHARACTERISTICS

OF THE WALNOT CREEK BASIN

DES MOINES METROPOLITAN AREA, IOMA

ABSTRACT

This report deals with the probable impact of urban development on the magnitude and frequency of flooding in the lower reach of the Nalnut Creek Basin.

Strean-modeling techniques, which include complete definition of unit hydrographs and precipitation loss-rate criteria, were utilized to evaluate the effects of urban development as measured by percentages of impervious area over the basin. A mathematical model, called HEC-1, was calibrated by using concurrent $r$ ainfall-runoff dat a collected at three gaging stations in the basin. The model parameters were regionalized to allow future users to estimate the model parameters for ungaged areas within the basin.

Long-term rainfall data recorded at two nearby stations were employed as basic input to the calibrated model to generate annual peak discharges corresponding to selected degrees of urbanization. Results are presented in tables and graphs, which conpare the pre-urban and urban flood flow characteristics of the lower reach of the walnut Creek basin. 


\section{INTRODUCTION}

Purpose and Scope

Walnut Creek basin, located within the Des Moines metropclitan area, is one of the more rapidly urbanizing areas in the state of Iowa. A particularly significant aspect of this trend is its effect upon the natural hydrologic system of the basin.

The specific objective of this study was to assess the impact of urban development on the magnitude and frequency of flocding in the lower reaches of the palnut creek basin.

Observed flood data of adequate period of record are, obviously, the nost reliable source for directly evaluating the consequences of urban development. Lacking these data, as in the Nalnut creek basin, where only 5 years of flood records are available, planners must resort to other sources of usable information and alternate methods of analysis. A surrogate approach often employed in urban planning is known as deterministic modeling or system simulation. According to McGuinness and others (1970),"... deterministic oriented mathematical models of watershed systems appear to offer the most rational approach both for quantitatively describing hydrologic performance of watersheds and for delineating the effects of land use and ma nement practices on stream flow".
Based on the preceding reasoning, a deterministic modeling method was utilized in this study. In general, the steps selected to implement this study can be summarized as follows:

1. Using a rainfall-runoff model, extend the short-term annual flood peaks at the gaging station by utilizing the long-term climatic data recorded at the nearby Des M cines airport and at Perry, Iowa.

2. Using watershed simulation techniques, generate concurrent long term annual peaks for selected degrees of urbanization.

3. Fit flood-frequency curves to the generated annual peak. arrays .

This report describes the simulation technique which was employed and sumarizes the results of the investigation.

This report was prepared by the 0.S. Geological survey under the administrative direction of $\mathrm{S}$. W. Hitala, District Chief. and is the result of a 3 -year cooperative agreement between the Geological Survey and the Iowa Natural Resources Council.

The a uthor is grateful to Arlen D. Feldan of the Corps of Engineers Hydrologic Engineering Center, Davis, California, for his advice, assistance, and cooperation in supplying computer programs and documentation. 


\section{STODY AREA}

The Mal nut Creek basin is in parts of Dallas and Polk Counties, as shown on the location map (fig. 1).

Walnut creek is a left-bank tributary of the Raccoon River and flows in a southeast direction entering the Raccoon River within the city limits of Des Moines. The lower portions of the basin consisting of about 8 to 10 percent of the total area is highly urbanized. Nearly all the remaining area is agricultural with approximately 75 percent in cropland. The predominant soil type is a combination of Clarion and Nicollet (Stevenson and Brown, 1922), which are classified in the hydrologic group $B$ (0.S. Soil Conservation Service, 1972). Soils in this group are characterized by moderate infiltration rates.

Elevation in the basin ranges from 850 to 1,050 feet above mean sea level. The topography varies from nearly level to rolling terrain. The average annual precipitation is about 32 inches, most of it falling during freeze-free periods.

\section{RAINFALI-RUNOFP MODEL}

A model called HEC- 1 wich was developed by the Hydrologic Engineering Center, 0.S. Army Corps of Engineers, (1973), was selected for use because it satifies the project requirements, is relatively simple to use, and it requires less data than alternate models.

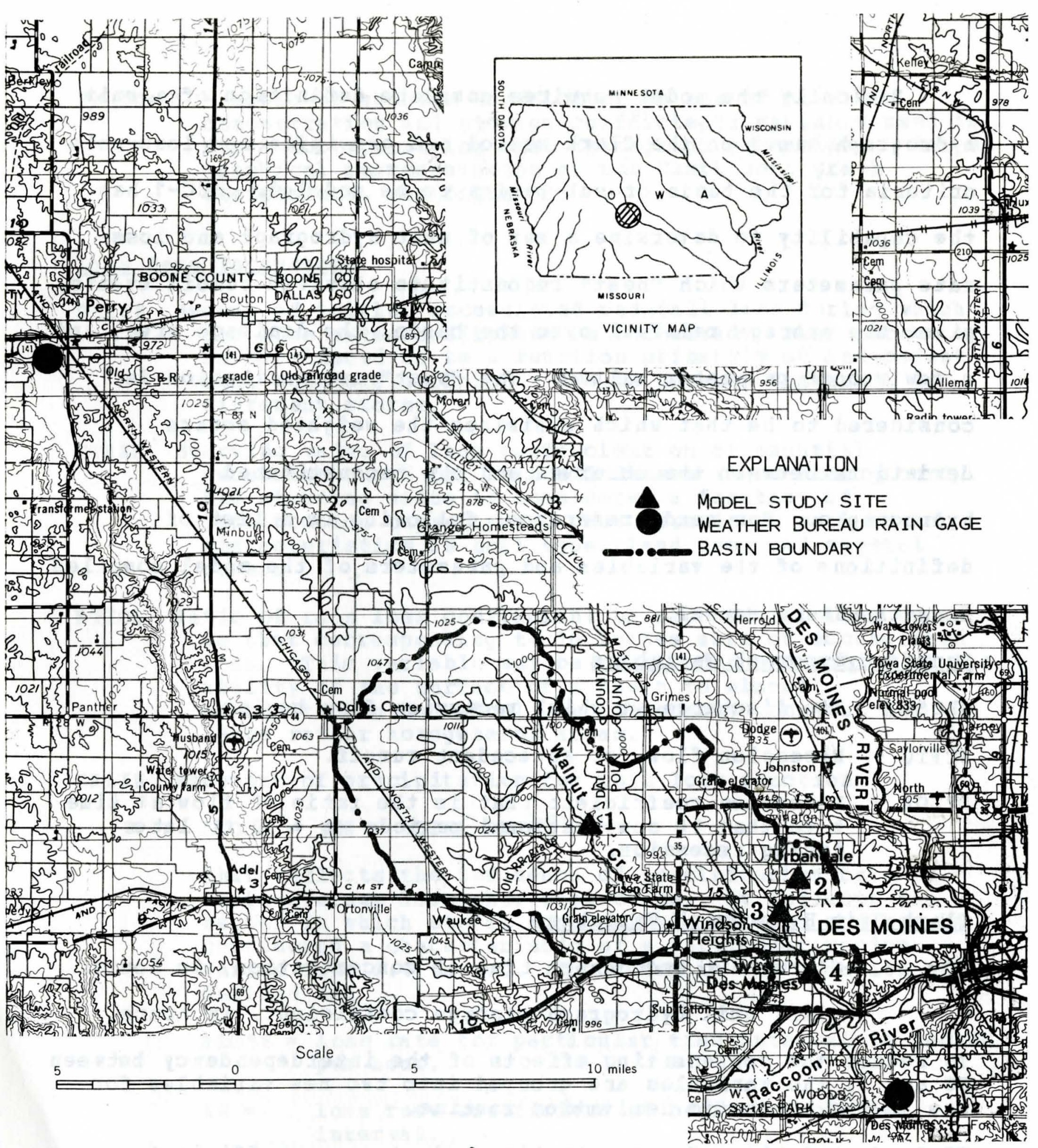

Walnut Creek near Grimes $\left(30.0 \mathrm{mi}^{2}\right)$

3 North Walnut Creek tributary at 14 ive

4 Walnut Creek at Des Moines $\left(78.4 \mathrm{mi}^{2}\right.$ )

Figure 1. Map of Walnut Creek basin, lowa. 
Basically the model requires complete definition of a unit hydrograph based on the clark method and precipitation loss-rate criteria for the basin or sub-basins to be modeled. HEC-1 has the capability to determine a set of unit hydrograph and lossrate parameters which "best" reconstitute observed runoff events, given the average rainfall over the basin, the drainage area, and a few runoff parameter values. The "best" reconstitution is considered to be that which minimizes the weighted square deviations between the observed and the reconstituted

hydrographs. For ready reference, following is a list of definitions of the variables and parameters of the model compiled from the osers Manual.

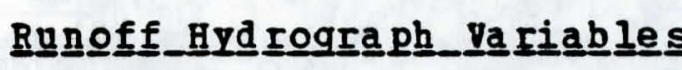

QRCSN - The discharge at which recession flow begins.

STRTQ - Recession flow for antecedent runoff.

RTIOR - Recession coefficient that is the ratio of flow at time $t$ to that 10 computational periods $(t+10 t)$ later

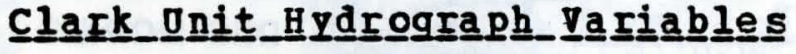

TC clark unit hydrograph time of concentration, in hours. R Clark unit hydrograph storage coefficient, in hours.

To reduce the compensating effects of the interdependency between TC and $R_{\text {o the }}$ variables are grouped into two new variables for use in the atomatic derivation routine.

TC+R Sum of time of concentration and storage coefficient, variable used in HEC- 1 for optimizing unit hydrograph parameters.
R/ (TC+R) - Ratio of storage coefficient to sum of time of concentration and storage coefficient: Variable used in BEC-1 for optimizing unit hydrograph paraneters. For a graphical representation of the clark unit graph coefficient, see figure 2 .

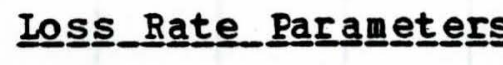

DLTKR Amount of initial accumulated rainfall loss during which the loss ra te coefficient is increased. This parameter coil moisture deficiency and is usually different for different storas.

STRKR Starting value of loss coefficient on exponential recession curve for rainfall losses (snow-free ground). The starting value is considered a function of infiltration capacity and thus depends on such basin characteristics as soil type, land use, and veget al cover.

RTIOI Ratio of rain loss coefficient on exponential loss curve to that corresponding to 10 inches more of accumulated loss. This variable may be considered a function of th ability of the surface of a basin to absor $b$ precipitation and should be reasonably constant for large rather homogeneous areas.

ERAIN Exponent of precipitation for rain loss function ALOSS $=($ AK + DLTK) PRCPERAIN

that reflects the influence of precipitation rate on basin-average loss characteristics. It reflects the manner in which storms ccur within an area and may 7 aries from 0.0 to 1.0 . The terns in the equation are

A LOSS = loss rate for particular time interval in inches per hour.

$A K=$ loss rate coefficient at beginning of time interval.

PRCP = rainfall intensity in inches per hour $\begin{aligned} & \text { DITK }= \text { incremental increase in loss rate coefficient. } \\ & \text { DITK is assumed to be a parabolic function of }\end{aligned}$ 


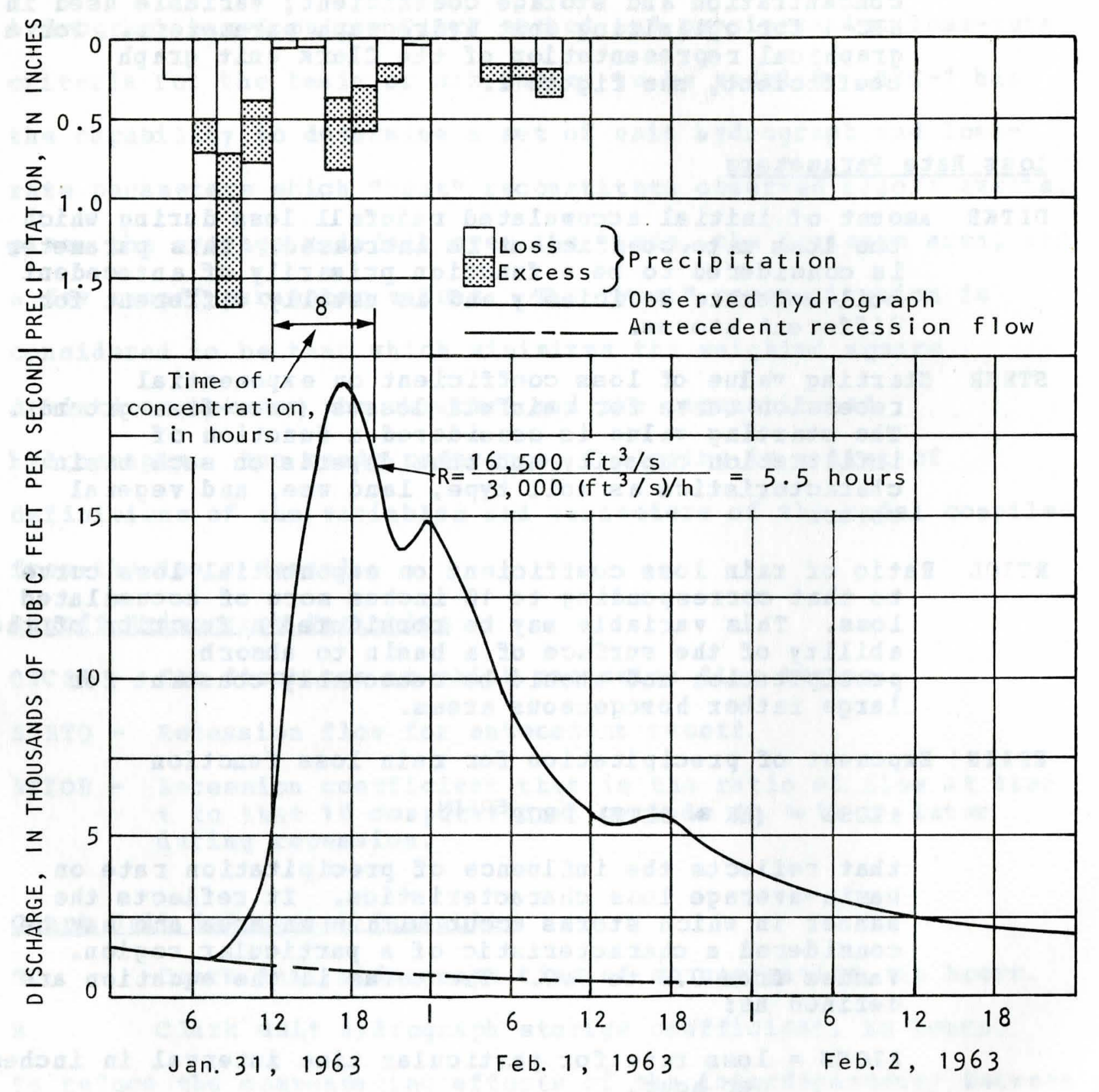

TIME, IN DATE AND HOURS

Figure 2. Clark unit graph coefficients. the accumulated loss for DITKR amount of accumulated loss. DLTK is a maximum of 0.2 DITKR initially reducing to zero when the accumulated loss equals DLTKR. A graphical ill ustrated in figure 3 .

BASIC DATA

During the first year (1975) of this three-year project, a data-collection network was established to obtain concurrent streamflow and rainfall data. The gaging stations in the basin were installed in accordance with the following criteria:

1. Opdate the instrumentation at the recording station near the mouth of Walnut Creek which has been in operation since 1971.

2. Select a site in the basin to collect data for an essentially rural area.

3. Select a site in the basin to collect data for a partially urbanized area.

4. Select a site in the basin to collect data for a completely urbanized area.

5. Assure that stations in the network represent a significant $r$ ange of drainage-area sizes.

Budget constraints linited the number of gaging stations to four including the existing gaging station. Each gaging site was equipped with a Stevens A-35 water-stage recorder with a rainfall recording attachment. Figure 1 shows their locations. 


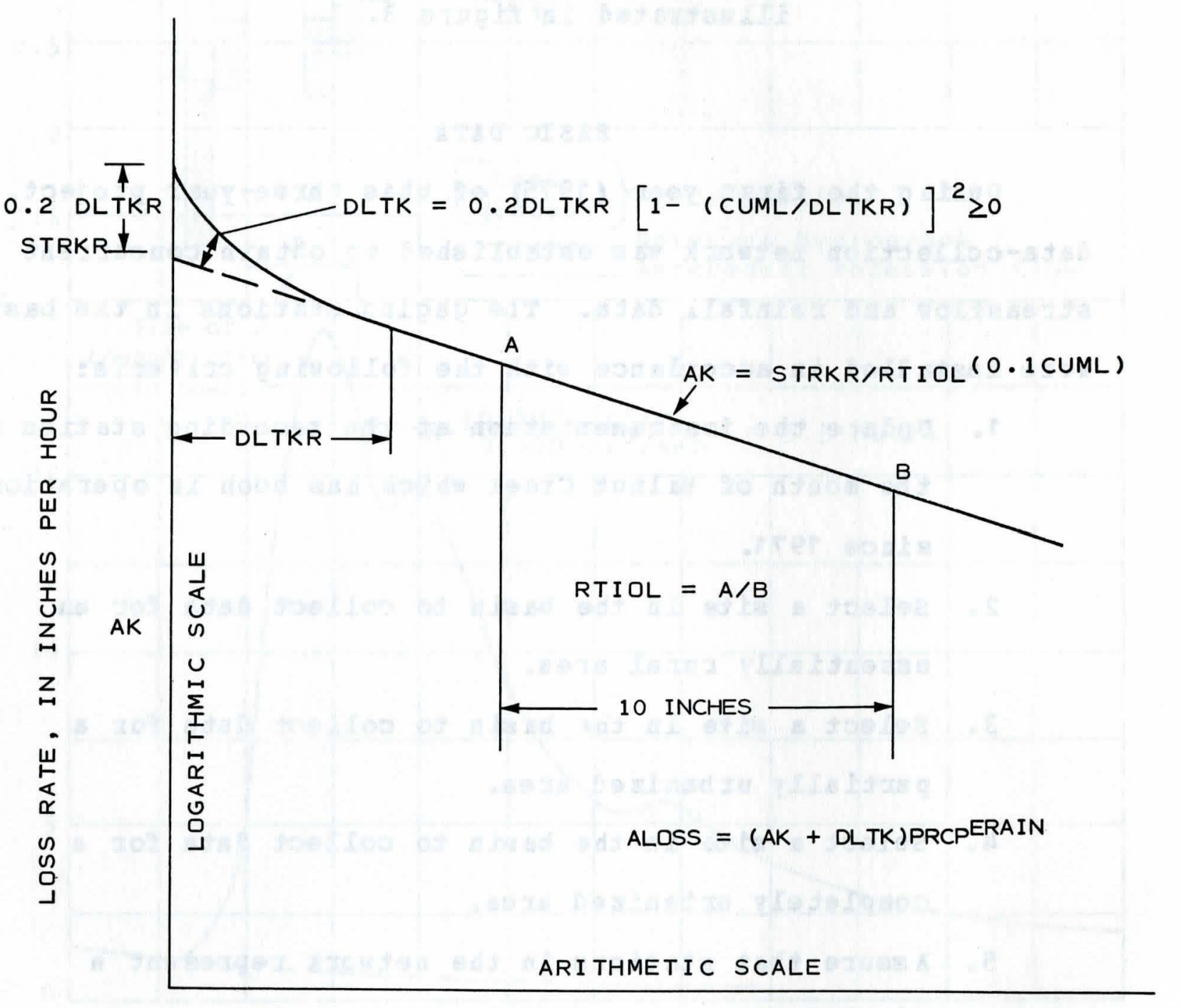

ACCUMULATED LOSS (CUML), IN INCHES
Data-collection expectations were not fully realized because the study area, experienced severe drought conditions with very little storm activity. This situation persisted throughout the time of the project limiting the collection of data to no more than two or three significant storms at each gaging station. Furthermore, the location of the gage installed to collect data for a fully urbanized area proved to be unsatisfactory and had to be moved. Hence, data from only three stations were available at the time of this study (1977).

other data used in this study were long-term records of hourly rainfalls at the Des Moines airport and concurrent 24-hour total rainfall amounts recorded at Perry. Iowa. The locations of these rainfall stations are show in figure 1.

\section{MODEL CALIBRATION}

Regional Analysis of Model parameters

The usefulness of a calibrated model, such as the one described above, is considerably expanded by providing future investigators with the ability to estimate the model parameters for ungaged areas within the basin. This was accomplished by regionalization techniques in which model parameters were related to physiographic, land-use, and climatic characteristics of the basin. Regionalization of model parameters is not one of the primary objectives of the present study. However, efforts have been made at this time to develop a set of criteria for 
estimating model parameters for ungaged watersheds within the Halnut creek basin.

The modeling sequence and the results of the regionalization studies are summarized below.

$$
\text { Modeling Sequence }
$$

The calibration of the model and definition of regional relations were accomplished generally in the following seguence.

1. C cmpile precipitation and runoff data for all of the storms at the gage.

2. Determine STRTQ for each storm at the gage.

3. Determine QRCSN for the recorded flood by plotting the flow recession on semilogarithmic paper and selecting the discharge above which the recession significantly departs from a linear relation.

4. Determine RIIOR. This value is equal to the slope of the linear function discussed in step 3.

5. Compute TC, R, STRKR, DITKR, RTIOI, and ERAIN for all storms at the gage using the optimizing routine of the model.

6. Repeat steps 1 through 5 for all gages in the basin. Based on the results, select an average regional value f or ERAIN.
7. Repeat Step 5 for all gages and selected storms with ERAIN fixed to equal the regional value. Select a regional value for RTIOI based on previous computations.

8. Compute TC, $R$, STRKR, DITKR, using the optimizing routine of the model for all storms at all gages with the regional values of ERAIN and RTIOI fixed.

9. From the results of step 8 , select a representative value of STRKR for each $g$ age, and recompute $T C_{,} R_{,}$and DITKR for all gages and storms with BRAIN, RTIOI, and STRKR fixed.

10. Select an appropriate value for DITKR and an average value for $R / T C+R$ for each subbasin and optimize $T C$ and $R$, with $R / T C+R$, STRKR, ERAIN, DITKR, and RTIOI fixed for the selected storms at each gage.

11. Select an average representative value of $\mathrm{TC}$ and $\mathrm{R}$ for each stream, check the goodness of fit of selected storms. Adust $T C+R$ and rerun if needed.

12. Regionalize the model parameters.

13. To judge the quality of the regional approach compute the model parameters by using the regional relations and reconstitute known runoff events at each site and compare. Examples of such comparisons are shown in figures 4, 5, and 6 . In addition, the final rainfallr unoff values were compared to the relations developed by the Soil conservation Service (1972) where lcss rates 


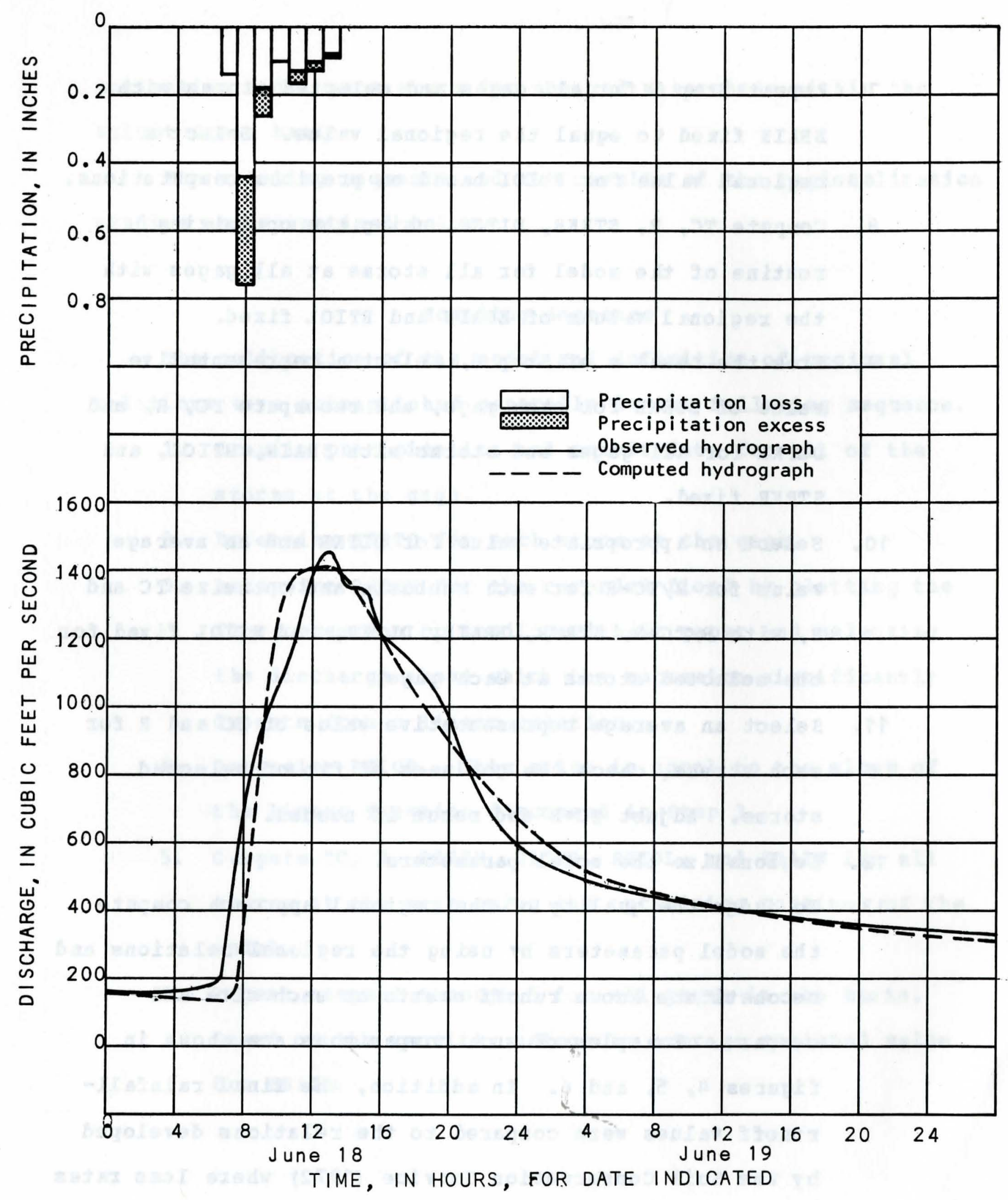

Figure 4. Observed and computed hydrographs for Walnut creek at Des Moines, lowa (drainage area, $78.4 \mathrm{mi}^{2}$ ) for flood of June $18,1975$.

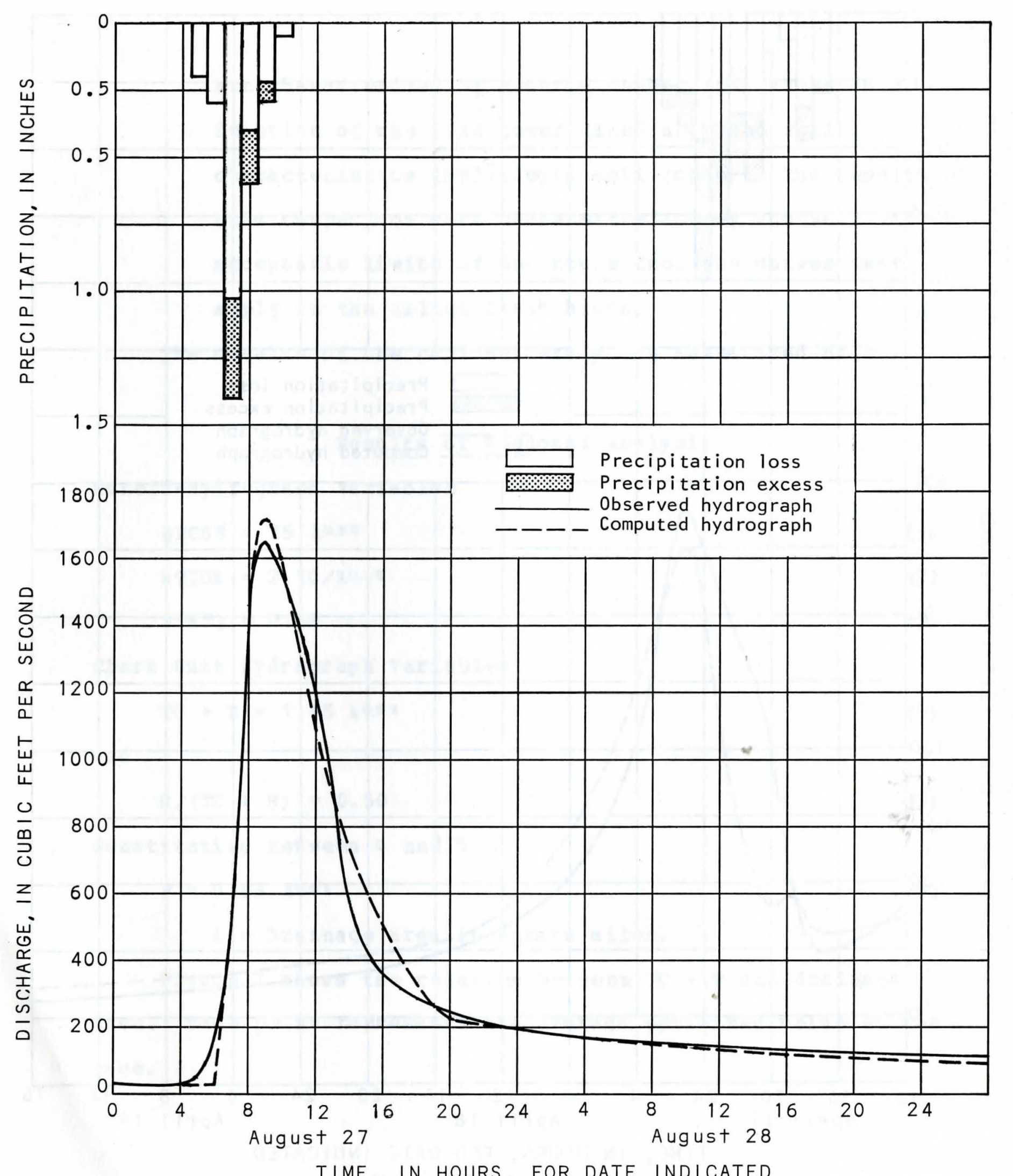

TIME, IN HOURS, FOR DATE INDICATED

Figure 5. Observed and computed hydrographs for Walnut Creek near Grimes, lowa (drainage area, $30.0 \mathrm{mi}^{2}$ ) for flood of June $18,1975$. 


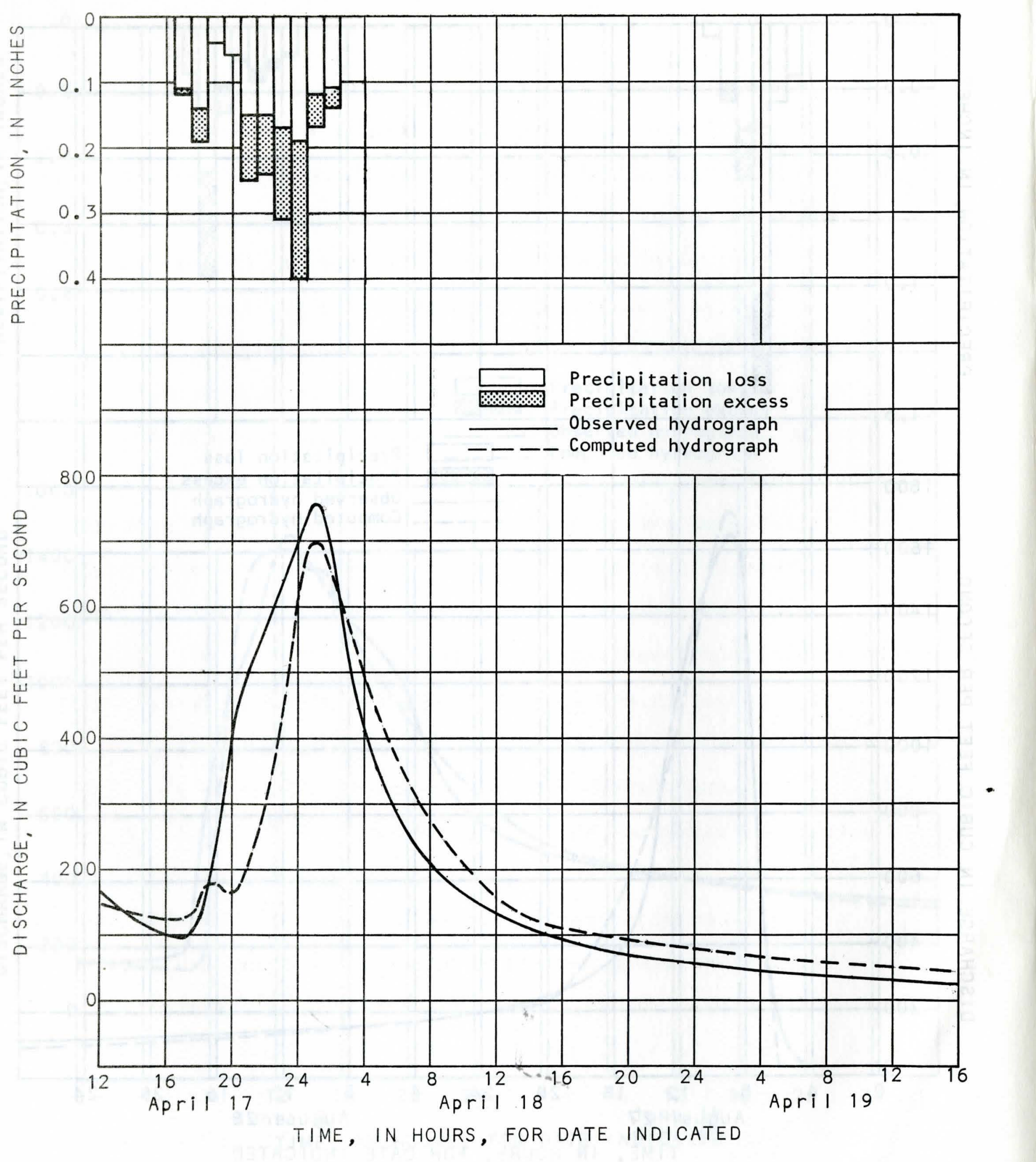

Figure 6. Observed and computed hydrographs for North Walnut Creek at College Drive (drainage area, $13.14 \mathrm{mi}_{2}^{2}$ ) for flood of April 18, 1976 are characterized by a curve number (CN) which is a function of the land cover (land use) and soil

characteristics (hydrologic soil group). The results of this comparison were quite satisfactory and well within acceptable limits of departure from the curves that apply to the walnut creek basin.

The results of the regional study are summarized below.

\section{Results of Regional Analysis}

Runoff-Hydrograph Variables

QRCSN $=35$ A 0.50

RTIOR $=2.10 / \mathrm{A}^{0.10}$

STR TQ $=0.5 \mathrm{~A}$

Clark Onit Hydrograph Variables

$T C+R=1.65 A 0.52$

and

$R /(T C+R)=0.50$

Substituting between 4 and 5

$R=0.83 \quad A^{0.51}$

A = Drainage area in square miles.

Figure 7 shows the relation between $T C+R$ and drainage area. Each point represents the average optimized value at the gage. 
Loss Rate Parameters

ERAIN $=0.54$

RTIOI $=2.94$

STRKR $=0.32$

DLTKR (function of antecedent conditions).

It should be noted that the results obtained from the regional relations are applicable only to the Malnut Creek basin.

\section{SY NTHESIS OP FIOOD PEAKS}

Processing of rainfall data

The rainfall-runoff model, calibrated as explained previously, was used to synthesize flood peaks using long-term rainfall records for Halnut Creek at Des Moines (drainage area $\left.78.4 \mathrm{mi}^{2}\right)$. Rainfall storms were selected from data recorded at the Des Moines airport and at Perry, Iowa.

The Des Moines rainfall-recording station has been in operation since 1879. However the time response of the basin is such that the mcdel re quires hourly rainfall distribution data. Therefore, only the 36-year record for 1941-76 water years is usable.

HEC-1 performs "l umped" parameter modeling. This means that the computed parameters and the input data, such as rainfall, are considered to be average values and, in the case of rainfall, uniformly distributed over the watershed. In order to meet this

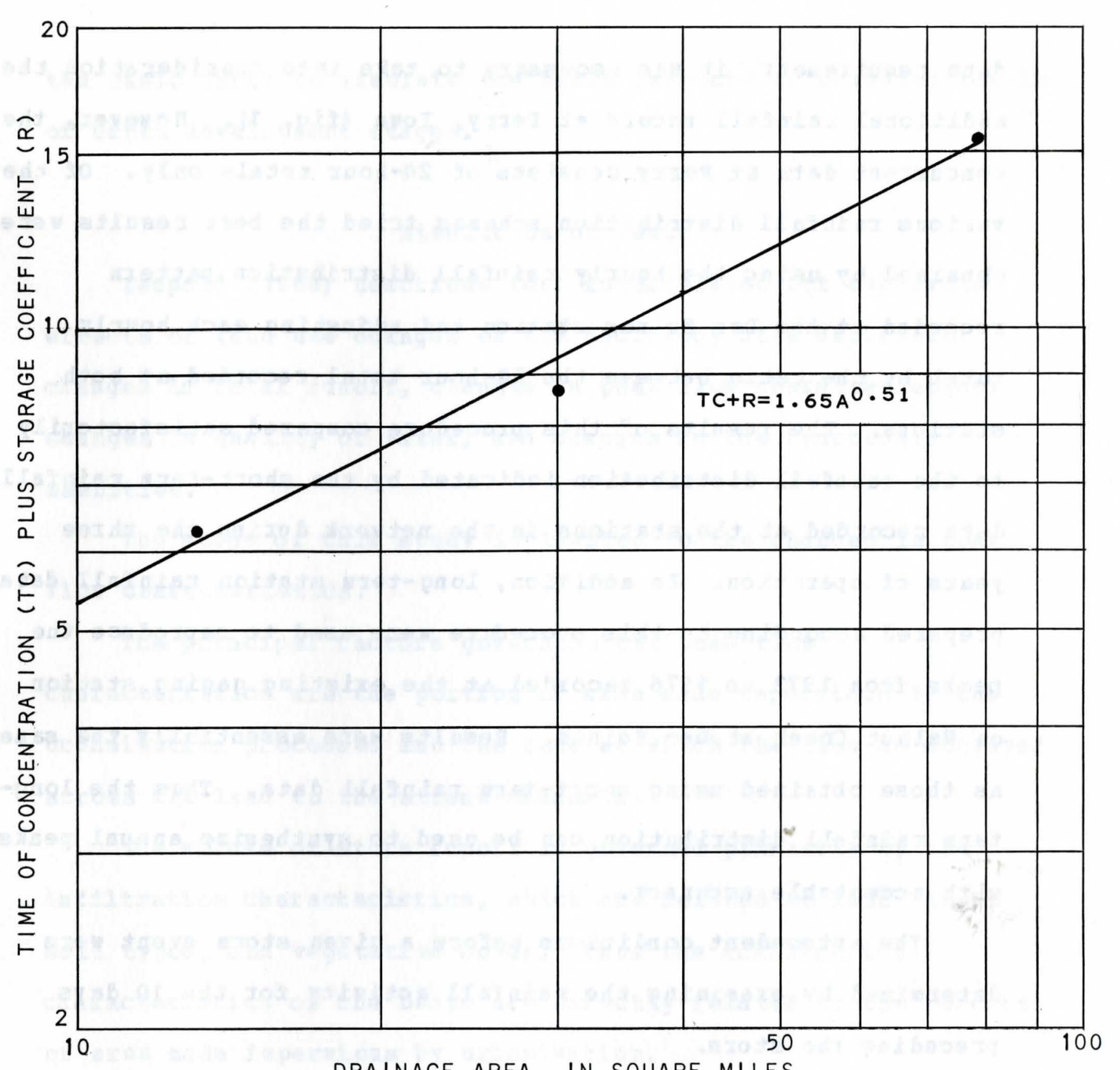

DRAINAGE AREA, IN SQUARE MILES

Figure 7. Relation between Clark unit hydrograph parameters and the drainage area for Walnut Creek basin. 
data requirement, it was necessary to take into consideration the additional rainfall record at Perry, Iowa (fig. 1). However, the concurrent data at perry consists of 24-hour totals on 19 . of the various rainfall distribution schemes tried the best results were obtained by using the hourly rainfall distribution pattern recorded at the Des Moines station and adjusting each hourly total by the ratio between the 24 -hour total recorded at both stations. The results of this procedure compared satisfactorily to the rainfall distribution indicated by the short-term rainfall data recorded at the stations in the network during the three years of operation. In addition, long-term station rainfall data prepared according to this procedure were used tc reproduce the peaks from 1972 to 1976 recorded at the existing gaging station on Walnut creek at Des Moines. Results were essentially the same as those obtained using short-term rainfall data. Thus the longterm rainfall distribution can be used to synthesize annual peaks with acceptable accuracy.

The antecedent conditions before a given storm event were determined by examining the rainfall activity for the 10 days preceding the storm.

All of the storm events in the long-term record which appeared likely to produce a high peak were simulated with the model. From these runs, the storm event wich resulted in the highest peak discharge within a water year was selected and included in an array of 36 annual storms. These data constitute the basic input to simulate the basin response to selected levels of urban development stages.

Simulation of Peaks

Leopold (1968) describes four interrelated but separable effects of land use changes on the hydrology of a watershed: changes in total runoff, changes in peak flow characteristics, changes in quality of water, and changes in the hydrologic amenities.

The scope of this study is limited to the changes in peak flow characteristics.

The principal factors governing the peak flow characteristics are the portion of area made impervious by the urbanization processes and the $r$ ate at which the flow is conveyed across the land to the stream channels.

The volume of storm runoff is governed primarily by the infiltration characteristics, which are related to land slope. soil types, and vegetative cover. Thus the infiltration characteristics of the basin are directly related to the percent of area made impervious by urbanization.

The $r$ ate at which water is conveyed across the basin is related to the density, size, and hydralic characteristic of the tributary channels. Therefore it is also related to the provision of storm sewerage systems, which alter the natural conditions of the basin. Observed data to develop relations 
describing the effect of channel modification on the unit hydrograph parameters are not available at this time. For the purpose of this study, factors for adjusting these parameters have been obtained from experimental data compiled by the soil Conservation Service (1975).

Results

To compare the effects of urbanization on the flood flow characteristics of Halnut creek, five simulation runs were made. The first run was for the basin in its present stage of urbanization (abcut 5 percent of the area impervious). The remaining runs vere made by changing the pertinent model parameters to reflect $20,30,50$, and 100 percent of the basin impervious. Taking into account the size of the drainage area and the type of urban development expected to take place, the upper limit is likely to be less than 50 percent impervious.

The synthetic annual peaks for each year of rainfall record are listed in Table 1.

Frequency curves for each of the annual peak series listed in Table 1, were computed by fitting the Pearson Type III distribution function to the logarithms of the annual peaks. The computed log-Pearson distribution parameters are listed at the bottom of Table 1. The resulting frequency curves are shown in figure 8 .
The variation of the log-Pearson type III distribution parameters with percent of impervious area is shown in figure 9. If desired, this figure could be used to calculate frequency curves between those shown in figure 8 .

Included in figure 8 and for the purpose of comparison, is a "regional frequency curve" which was estimated by using an entirely different approach from the one discussed in this report. Methods for estimating regional flood-frequency curves for the state of Iowa are explained by Lara (1973, 1974). Theoretically, the regional curve describes the flood-frequency characteristics of walnut creek in its natural condition.

The $i$ mpact of urbanization on the flood-frequency characteristics of Walnut Creek, as measured by increasing percentages of impervious area over the basin, can be evaluated from the data summarized in table 1 and figure 8. 
Table 1. Synthetic annual peak discharges, in cubic feet per second. compiled from model responses to present conditons and to selected degrees of ur

\begin{tabular}{|c|c|c|c|c|c|}
\hline \multirow{2}{*}{$\begin{array}{r}\text { Water } \\
\text { year }\end{array}$} & \multicolumn{5}{|c|}{ - Imper vious ar ea over the basin in percent } \\
\hline & present & & & & \\
\hline 1941 & 4080 & 4870 & 5230 & 5800 & $\overline{6} \overline{3} \overline{0}$ \\
\hline 1942 & 4140 & 5430 & 6030 & 6850 & 9390 \\
\hline 1943 & 1890 & 2510 & 2820 & 3350 & 4670 \\
\hline 1944 & 2870 & 3720 & 4140 & 4930 & 6500 \\
\hline 1945 & 2230 & 3180 & 3660 & 4530 & 6320 \\
\hline 1946 & 2000 & 2820 & 3240 & 3970 & 5430 \\
\hline 1947 & 5310 & 6600 & 7190 & 8390 & 10400 \\
\hline 1948 & 3280 & 4200 & 4730 & 5650 & 7400 \\
\hline 1949 & 1970 & 3020 & 3560 & 4570 & 6480 \\
\hline 1950 & 2820 & 3570 & 4040 & 4870 & 6300 \\
\hline 1951 & 2640 & 3630 & 4120 & 5080 & 6880 \\
\hline 1952 & 3380 & 4090 & 4430 & 5040 & 6340 \\
\hline 1953 & 790 & 1420 & 1770 & 2430 & 3810 \\
\hline 1954 & 4790 & 5980 & 6550 & 7680 & 9480 \\
\hline 1955 & 2200 & 2860 & 3210 & 3830 & 5200 \\
\hline 1956 & 345 & 818 & 1070 & 1550 & 2660 \\
\hline 1957 & 775 & 1180 & 1400 & 1780 & 2740 \\
\hline 1958 & 6890 & 8570 & 9360 & 10800 & 12700 \\
\hline 1959 & 2350 & 3320 & 3790 & 5150 & 7210 \\
\hline 1960 & 4010 & 5130 & 5700 & 6740 & 8600 \\
\hline 1961 & 3600 & 4910 & 5550 & 6840 & 8850 \\
\hline 1962 & 2830 & 3600 & 3970 & 4570 & 5690 \\
\hline 1963 & 6030 & 7370 & 7990 & 9170 & 10800 \\
\hline 1964 & 2260 & 2980 & 3380 & 4110 & 5440 \\
\hline 1965 & 1730 & 2400 & 2740 & 3370 & 4670 \\
\hline 1966 & 1630 & 2180 & 2470 & 2940 & 4020 \\
\hline 1967 & 3080 & 3750 & 4090 & 4580 & 5700 \\
\hline 1968 & 3810 & 4810 & 5390 & 6320 & 7990 \\
\hline 1969 & 1170 & 1990 & 2390 & 3170 & 4830 \\
\hline 1970 & 3220 & 4120 & 4560 & 5460 & 6770 \\
\hline 1971 & 1630 & 2610 & 3130 & 4100 & 5970 \\
\hline 1972 & 672 & 1360 & 1700 & 2370 & 3850 \\
\hline 1973 & 8990 & 10800 & 11600 & 13400 & 15400 \\
\hline 1974 & 8120 & 10000 & 10900 & 12800 & 14800 \\
\hline 1975 & 5840 & 7290 & 8000 & 9340 & 11400 \\
\hline 1976 & 2450 & 3310 & 3750 & 4540 & 6140 \\
\hline Mean & 3.417 & 3.555 & 3.609 & 3.694 & 3.819 \\
\hline S.D. & 0.307 & 0.251 & 0.235 & 0.215 & 0.180 \\
\hline
\end{tabular}

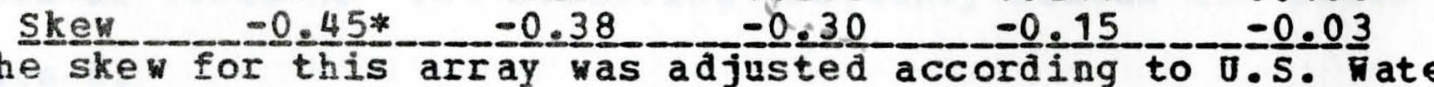
* The skew for this array was adjusted accord. It was a ssume that these peaks represents closely the natural conditions of the basin. No other adjustments were made.
PROBABILITY OF OCCURRENCE, IN PER CENT

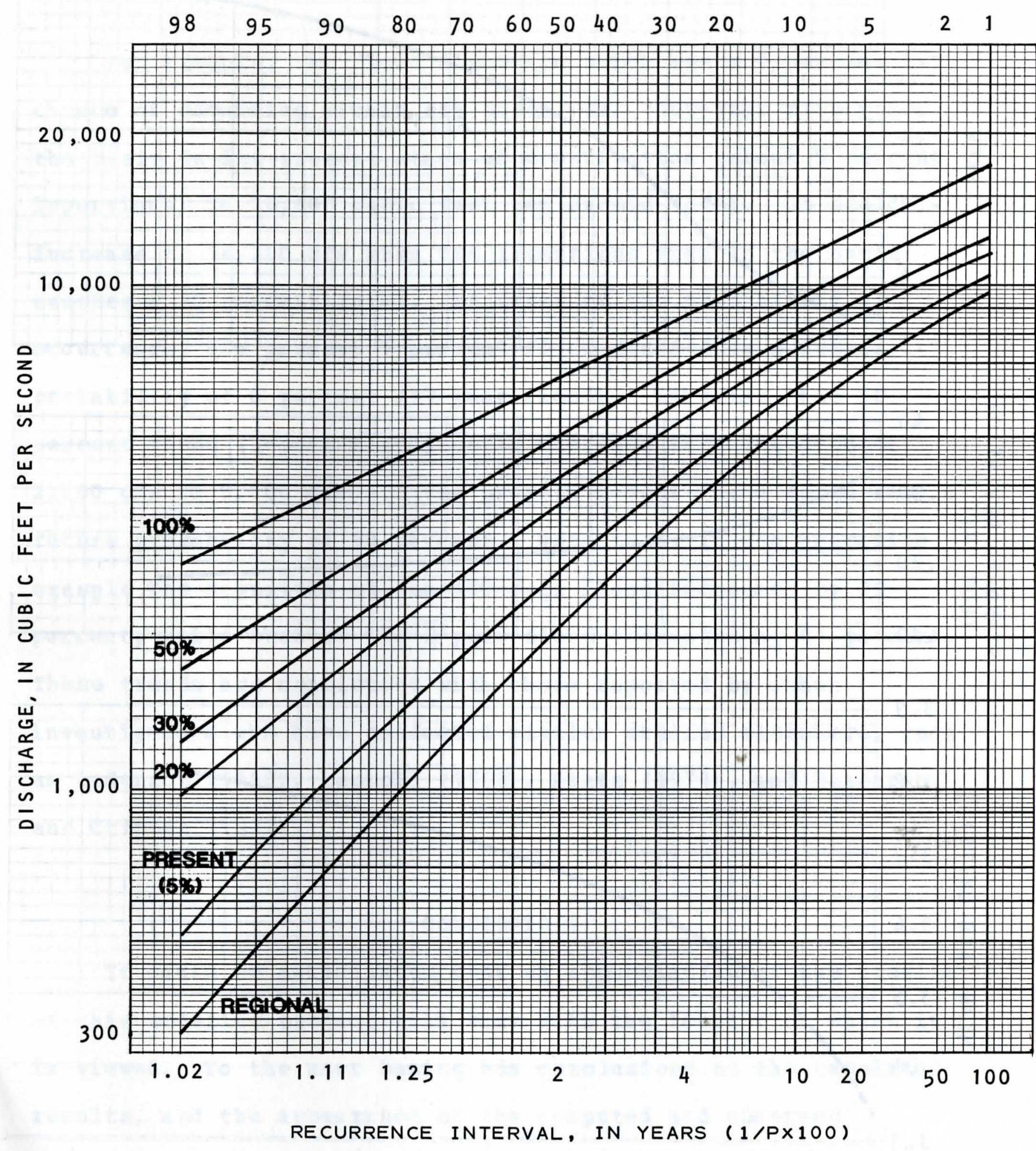

Figure 8. Flood frequency curves showing the effect of urbanization as measured by increased percentage of impervious area for Walnut Creek at Des Moines. 

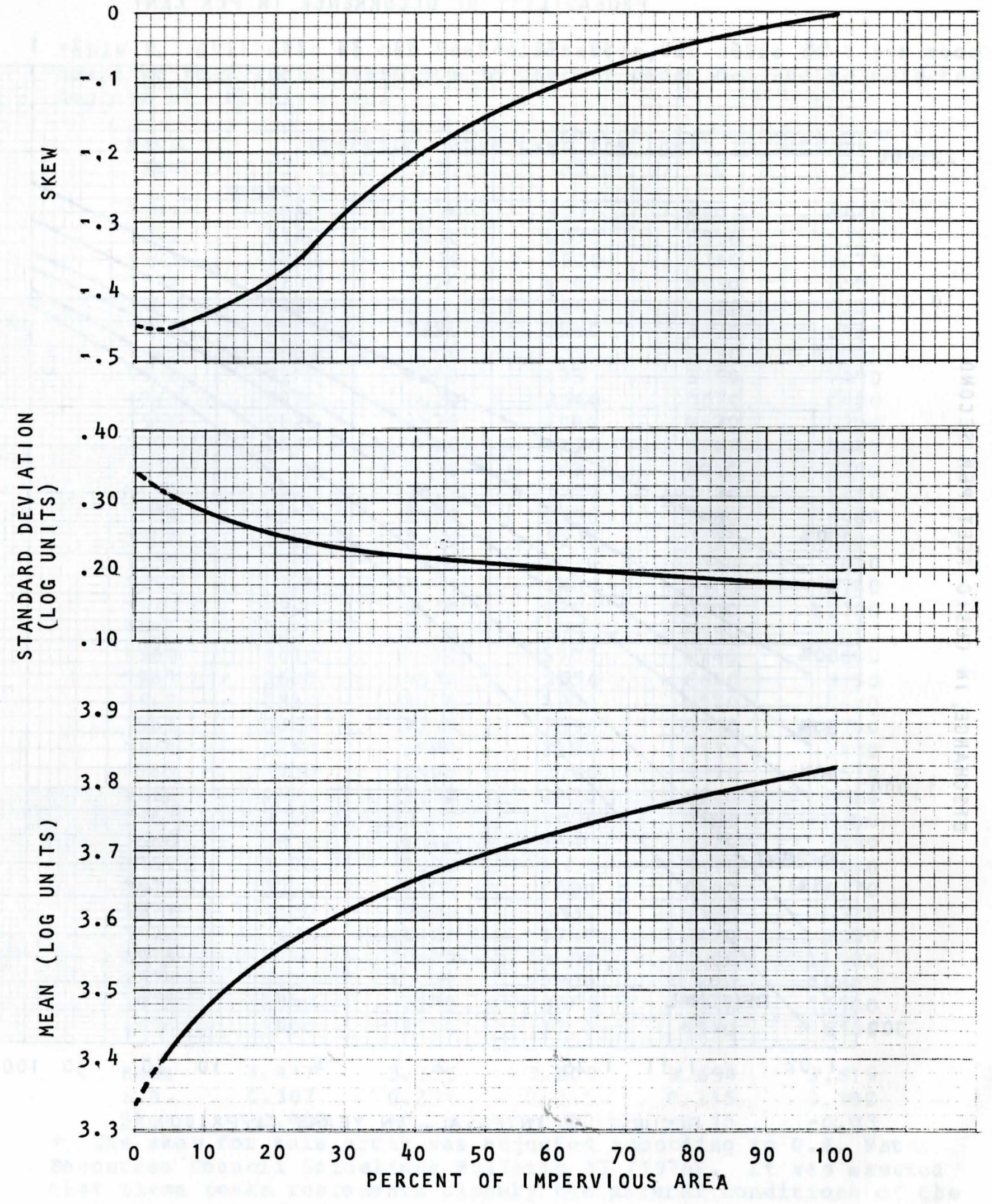

Figure 9. Relations between the log-Pearson type III distribution parameters and percent of impervious area for Walnut Creek at Des Moines.
For example, the flood discharge which has a 1 percent chance of occurring within any given year (100-year flood) for the basin in its present stage of urbanization (about 5 percent impervious) is 10,600 cubic feet per second (cfs). It could increase to 14,700 cfs when the impervious area in the basin reaches a 50 percent level. In terms of the probability of occurrence, the present 1 percent flood could have a future probability of 6 percent (17-year flood). Likewise, the 50 percent flood (2-year flood) could increase from the present $2,760 \mathrm{cfs}$ to $5,000 \mathrm{cfs}$, or the present 2 -year flood could have a future probability of 90 percent. Note that, in the preceding example the magnitude of the 100-year flood increases by 39 percent. while that of the 2-year flood increases by 81 percent. These trends are consistent with those reported by other investigators who have conducted similar studies elsewhere, such as Anderson (1968), Leopold (1968), Rantz (1971), and waananen and crippen (1977).

\section{CONCLUSIONS}

It could be anticipated that an appreciaticn of the results of this modeling project will vary with the level from which it is viewed. To the user basing his conclusions on the tabulated results, and the appea rance of the computed and observed hydrographs, it may suggest that the complexities of the rainfall-runoff relations in the Walnut Creek basin have been 
satisfactorily explained. To the modeler who has had to struggle with data which may be inadequate and assumptions which may not be entirely satisfactory, it may appear that the results are tentative and in need of further refinement. Because this report has been prepared for the benefit of the user as well as the modeler, it is appropriate to point out briefly its strong points, identify its weaknesses, and suggest possible future studies.

Among its strengths are the conclusions derived fron this study, which appear to be consistent and in close agreement with the results reported by investigators who have conducted sinilar studies elsewhere in the nation.

The reader also is referred to figure 8 to observe the close agreement between the synthetic frequency curve corresponding to the basin in its present state and the regional frequency curve. which theoretically represents the flood flow characteristic of the basin in its natural state. Considering that the basin is presently about 5 percent impervious, the agreement is indeed remarkable. Hence, another element of strength is the fact that the results from a simulation approach have been verified by the results of a widely used and accepted technique, which uses a statistical approach.

The obvious shortcoming and most probable source of criticism are the limited runoff data available to conduct this study. In addition there is a lack of recorded data concerning the effect of sewered or improved channels on the time of concentration and storage characteristics of the watershed and subbasins.

The above remarks are not intended in any way to demean the information presented in this report. By describing the strengths and deficiencies, the intention is to underline the confidence with which the information may be placed to practical use.

In reference to $\mathrm{f} u r t h e r$ studies in this basin, there is a need to develop a set of flood-routing criteria, similar to the unit hydrograph and loss-rate criteria developed in this study. A set of routing criteria would give the users of this madel the capacity, for example, to evaluate the impact of a project in a distant tributary of the basin on the flood-flow characteristics at a downstream location, or to conduct comprehensive flood-plain management studies, such as the one outlined by Davis (1976) for the oconee River basin in Georgia and Farnham (1977) for the Crow Creek basin in Iowa. 
Anderson. D. G. 1968, Effects of urban development on floods in rson, D. G. 1968, Effects of urban development on floods in
northern virginia: 0.5 . Geol. Survey open-file rept.. 39 p.

Davis, D. N. 1976, Comprehensive flood plain studies using spatial data magement techniques; Paper presented at the Illin ois.

Farnham, C. W. , 1977, Land use management assistance. Paper presented at the Twenty-fifth Annual Public Norks Conference, ames, Iowa.

Lara, O. G.. 1973, Ploods in Iowa: Technical manual for estimating their magnitude and frequency, Iowa Natural Resources Council Bull. N0.11, 56 p.

- 1974 , floods in I owa: A comparative study of regional lood-frequency methods: Iowa Natural Resources Council Bull. No. 12, 67 p.

Leopold, I. B., 1968, Hydrology for urban land planning, A guidebook on the hydrologic effects of urban land use, 0.S. Geol. Survey Circ. 554, 18 p.

HCGuiness, J. I, Dragoun. F. J.. and Harrold, L. L.. 1970, Status of findings on agricultural land use changes, Paper presented at the Annual leeting a merican Geophysical onion, prese 1970, Hashington, D.C.

Rantz, S. E., 1971, Suggested criteria for hydrologic design of storm drainage facilities in the San Francisco Bay Region. California: 0.s. Geol. Survey open-file rept.. 69 p.

Stevenson, . H.. Brown, P. E. 1922, Soil Survey of Iowa, report No. 24, Polk County Soils, Iowa Agriculture Experiment Station.

0.S. Army Corps of Engineers, 1973, HEC-1 Flood hydrograph package, Users manual, Hydrologic Engineering Center Computer Progra 723-x6-L2010, Davis, California.

o.s. Soil Conservation Service, 1972, Hydrology: National engineering handbook, Sec. 4, Mashington, D.C.

- 1975, Urban hyd rology for smail watersheds. Technical Release No. 55.

0.S. Water Resources Council, 1976, Guidelines for determining flood-flow frequency: Bull 17 . 




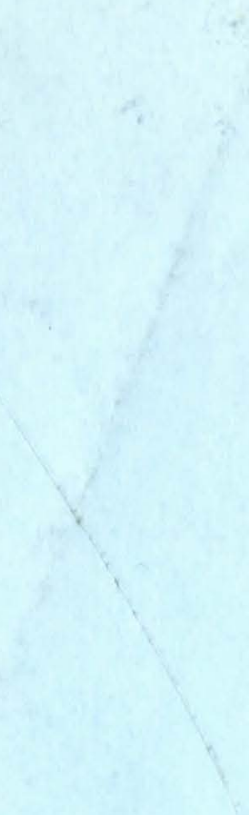

$*$

$+7$ 